Duncombe, W. G. (1964). Clinica Chimica Acta, 9, 122.

Eggstein, M. (1966). Klinisch Wochenzeitschrift, 44, 267. Hales, C. N., and Randle, P. J. (1963). Lancet, 1, 200. Hånsen, A. P. (1970). Fournal of Clinical Investigation, 49, 1467. Jackson, W. P. U., Goldin, C., and Marine, N. (1966). South African Medical fournal, 40, 206.

Lundbaeck, K., et al. (1970). Lancet, 2, 131.

McKiddie, M.'T., Buchanan, K. D., and Hunter, I. A. (1969). Quarterly Fournal of Medicine, 38, 445 .

Schalch, D. S., and Parker, M. L. (1964). Nature, 203, 1141.

Seftel, H. C., Isaacson, C., and Bothwell, T. H. (1960). South African

fournal of Medical Science, 25, 89

Seftel, H. C., and Walker, A. R. P. (1966). Diabetologia, 2, 286.
Szanto, S., and Yudkin, J. (1969). Postgraduate Medical fournal, 45, 602. Tulloch, J. A. (1966). Diabetes Mellitus, ed. L. J. P. Duncan, p. 115. Edinburgh, University Press.

Wapnick, S., Wicks, A. C. B., Kanengoni, E., and Jones, J. J. (1972). Lancet, 2, 300.

Watson, D. (1960). Clinica Chimica Acta, 5, 637.

van der Westhuysen, J., Mbizvo, M. T., and Jones, J. J. (1972). Lancet, 2, 719.

Wicks, A. C. B., Castle, W., and Gelfand, M. (1972). Diabetes. In press.

Wicks, A. C. B., and Clain, D. C. (1973). In preparation.

Yalow, R. S., Glick, S. M., Roth, J., and Berson, S. A. (1965). Annals of the New York Academy of Sciences, 131, 357.

Youngs, G. (1972). Gut, 13, 154.

\title{
Chronic Bronchitis: Method of Cigarette Smoking
}

\author{
J. RIMINGTON
}

British Medical fournal, 1973 1, 776-778

\section{Summary}

Male volunteers for mass radiography examination, aged 40 or more, were questioned about their sputum production, smoking habits, and, when applicable, their method of smoking cigarettes.

Of 5,438 cigarette smokers $460(8.4 \%)$ smoked their cigarettes without removing the cigarette from the mouth between puffs ("drooping" cigarette smokers) whereas the rest smoked in the normal manner.

Persons who admitted to producing sputum from their chests on most days of the year or on most days for at least three months of the year for a minimum of two years were classified as chronic bronchitics in the absence of other causative disease.

The rate of chronic bronchitis among the "drooping" cigarette smokers $(41.5 \%)$ was considerably greater than that among those smoking cigarettes in the normal manner $(33.6 \%)$. The same pattern was maintained when age and cigarette consumption were standardized, though "drooping" cigarette smokers had a slight bias towards plain as distinct from filter cigarettes and towards a lower social class this was not sufficient to account for the excess of chronic bronchitis among those using this method of smoking.

\section{Introduction}

Brett and Benjamin (1968), in an investigation of mortality in relation to smoking habits of men employed in industry, pointed out that those cigarette smokers who made a habit of retaining the cigarette in the mouth between puffs ("drooping" cigarette smokers) had a higher rate of lung cancer than those who removed the cigarette from the mouth between puffs. The higher rate of lung cancer in the former group was maintained irrespective of the number of cigarettes smoked.

This paper describes an investigation into the rate of chronic bronchitis among "drooping" cigarette smokers and compares it with the rate among those smoking cigarettes in

St. Thomas' Hospital, Stockport SK3 8BL

J. RIMINGTON, M.D., Medical Director, Regional Mobile Chest X-ray Service, Southern Division, Manchester Regional Hospital Board the normal manner. The definition of chronic bronchitis for the purposes of this study is the production of phlegm from the chest during the last two years, either on most days of the year or on most days during at least three months of the year.

\section{Subjects and Methods}

The data were obtained during 1970 and 1971 by questioning men from industry or from the general public who volunteered for mass radiography and who were aged at least 40 .

A smoking history was taken which included the amount, type, duration, and method of cigarette smoking and, in particular, each cigarette smoker was asked if he made a habit of keeping his cigarette in his mouth for most of the time or whether he removed it between puffs. A cigarette smoker was defined as one who had smoked at least one cigarette a day for as long as a year (Doll and Hill, 1950), and those who had stopped smoking at least two weeks before attending for mass radiography were classed as ex-smokers. Hand-rolled cigarette smokers were counted as cigarette smokers, the amount of tobacco used being converted to cigarette equivalents ( $1 \mathrm{oz}$. $(28 \mathrm{~g})$ a week = four cigarettes a day). Mixed smokers-that is, those smoking at least one cigar a week or 1 oz. $(28 \mathrm{~g})$ of pipe tobacco a month in addition to their cigarettes-were excluded from the study.

Each volunteer was asked if he brought up or coughed up phlegm from his chest and, if so, whether this was on most days of the year or on most days for at least three months of the year, and for how many years he had done this. All volunteers with incomplete or invalid records $(2.4 \%)$ were excluded, as were 68 persons whose subsequent chest $x$-ray films showed disease or abnormality (other than changes sometimes seen in chronic bronchitics) which was thought likely to be the cause of their persistent sputum-for example, certain tuberculous disease, lung cancer, bronchiectasis, etc.

Most of the volunteers in this study lived or worked in towns within the South-east Lancashire conurbation.

\section{SMOKING HABITS}

The smoking habits of the volunteers are compared in table I with a nationwide sample taken in 1968 (Todd, 1969). The figures given for the nationwide sample are recalculations of the original figures after the exclusion of the mixed smokers. It will be seen that the smoking habits of the volunteers are almost identical with those of the nationwide sample. 
TABLE I-Smoking Habits of 10,414 Male Mass Radiography Volunteers (M.M.R.) aged 40 or more Compared with those of a Nationwide Sample (U.K.) taken in 1968

\begin{tabular}{|c|c|c|c|c|}
\hline \multirow{2}{*}{$\begin{array}{c}\text { Age Group } \\
\text { in } \\
\text { Years }\end{array}$} & \multicolumn{2}{|c|}{$\begin{array}{c}\text { Non-smokers Ex-smokers } \\
\text { Non-cigarette Smokers }\end{array}$} & \multicolumn{2}{|c|}{$\begin{array}{l}\text { Cigarette } \\
\text { Smokers }\end{array}$} \\
\hline & $\underset{(\%)}{\operatorname{M.M.R.}}$ & U.K. & $\underset{(\%)}{\operatorname{M.M.R.}}$ & $\begin{array}{l}\text { U.K. } \\
(\%)\end{array}$ \\
\hline $\begin{array}{l}40-59 * \\
60 \text { or more } \quad \cdots\end{array}$ & $\begin{array}{l}46 \cdot 0 \\
53 \cdot 5\end{array}$ & $\begin{array}{l}45 \cdot 5 \\
54 \cdot 5\end{array}$ & $\begin{array}{l}54 \cdot 0 \\
46.5\end{array}$ & $\begin{array}{l}54 \cdot 5 \\
45 \cdot 5\end{array}$ \\
\hline
\end{tabular}

U.K. sample 35 to 59 years.

\section{"DROOPING" CIGARETTE SMOKERS}

The numbers and percentages of cigarette smokers who retain the cigarette in the mouth between puffs-“drooping" cigarette smokers-are shown in table II by age group. It will be noted that the habit is less prevalent in the younger age group than in the older age group and that the overall percentage is 8.4 .

TABLE II-Number and Percentage of "Drooping" Cigarette Smokers by Age Group among 5,438 Male Cigarette Smokers who Volunteered for Mass Radiography and were Aged at least 40.

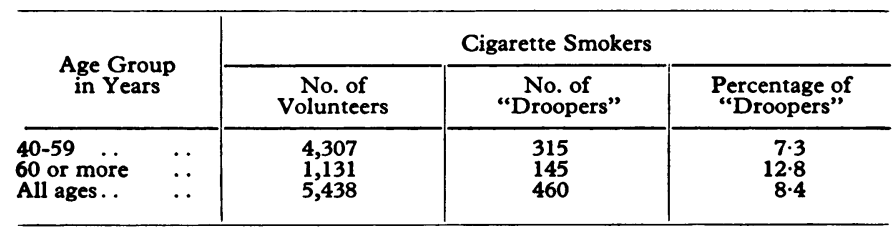

\section{CHRONIC BRONCHITIS PREVALENCE}

The sample was first examined for the percentage rates of chronic bronchitis in five-year age groups and it was obvious that these rates rose with increasing age, irrespective of smoking method and amount of tobacco consumed. Because of this, age standardized percentage rates of chronic bronchitis were calculated by basing them on a population equally divided in five-year age groups. These, together with the actual rates, are detailed in table III.

TABLE III-Number, Percentage, and Age-standardized Percentage of Chronic Bronchitics among 5,438 Cigarette Smoking Male Volunteers for Mass Radiography Aged at least 40, by Amount and Method of Smoking.

\begin{tabular}{|c|c|c|c|c|c|c|c|c|}
\hline & \multicolumn{8}{|c|}{ Cigarette Smokers } \\
\hline & \multicolumn{2}{|c|}{$\begin{array}{c}1-9 \\
\text { a day }\end{array}$} & \multicolumn{2}{|c|}{$\begin{array}{l}10-19 \\
\text { a day }\end{array}$} & \multicolumn{2}{|c|}{$\begin{array}{l}20+ \\
\text { a day }\end{array}$} & \multicolumn{2}{|c|}{ All } \\
\hline & D. & N. & D. & N. & D. & N. & D. & N. \\
\hline \multirow{4}{*}{$\begin{array}{l}\text { No. of volunteers } \\
\text { No. of chronic } \\
\text { bronchitics } \\
\text { Percentage chronic } \\
\text { bronchitics } \\
\text { Age-standardized } \\
\text { percentage of chronic } \\
\text { bronchitics }\end{array}$} & 60 & 581 & 134 & 1,839 & 266 & 2,558 & 460 & 4,978 \\
\hline & 22 & 150 & 56 & 552 & 113 & 971 & 191 & 1,673 \\
\hline & $36 \cdot 6$ & $25 \cdot 8$ & $41 \cdot 8$ & $30 \cdot 0$ & $42 \cdot 4$ & $37 \cdot 5$ & $41.5 *$ & $33.6^{\circ}$ \\
\hline & 33.9 & 26.0 & $41 \cdot 1$ & $32 \cdot 1$ & $44 \cdot 1$ & $41 \cdot 1$ & 41.6 & $35 \cdot 1$ \\
\hline
\end{tabular}

:P $\leq 0.001$.
D. $=$ "Drooping" cigarette smokers. N. = Normal cigarette smokers.

With regards to the cigarette smokers as a whole, the percentage of chronic bronchitics among "drooping" cigarette smokers $(41.5 \%)$ is much higher than among those smoking cigarettes normally $(33.6 \%)$. The difference is found to be of high statistical significance $(P<0.001)$. Moreover, the higher rate of bronchitis among "droopers" compared with the normal cigarette smokers is maintained in each consumption category. The age-standardized rates follow the same pattern.

\section{Discussion}

One must first consider the possibility that the findings may be suspect because of bias in selection. All samples based on mass radiography examinees are likely to be biased to some extent, but the present sample was restricted to volunteers from the public and industry while general practitioners' cases, contacts, prisoners, and other specially selected groups were specifically excluded. The smoking histories very closely corresponded to those of a nationwide sample of men over 40 (Todd, 1969), and the percentage of chronic bronchitics among the volunteers, while high, was no higher than that found in other investigations of similar symptoms among cigarette smokers of comparable ages (Higgins, 1959; Reid et al., 1964; Lowe, 1969).

There is also the possibility that other factors, important in the causation of chronic bronchitis, account for the difference between the "droopers" and normal cigarette smokers in respect of bronchitis. Age and amount smoked have been considered earlier and shown not to have been an influence here. Type of cigarette smoked (plain or filter) influences chronic bronchitis rates (Rimington, 1972) but the composition of "drooping" cigarette smokers in this respect (plain to filter ratio, $1: 1 \cdot 1)$ is not too different from that for the sample as a whole (plain to filter ratio, 1:1.27). The slightly lower proportion of filter smokers among the "droopers" coupled with the moderately lower percentage of chronic bronchitis found among filter smokers in the earlier study (Rimington, 1972) only accounts for $3 \%$ difference between the chronic bronchitis rates of "droopers" and "non-droopers" whereas the difference is $23.5 \%$ on actual rates.

Another possibly important factor could be a wide variation in the social class distribution of the two groups. A $10 \%$ sample of the occupational records was taken and the social class determined (General Register Office, 1960). In cigarette smokers as a whole the percentages in three social class groups (I and II, III, and IV and V) were 13, 63.5, and 23.5 respectively whereas the corresponding percentages among the "drooping" cigarette smokers were 8, 69, and 23. These distributions, taken into account with the type of gradient in chronic bronchitis with decline in social class found in other studies (College of General Practitioners, 1961; Rimington, 1969), could have, at most, only a minimal effect on the results.

It seems reasonable to assume that the excess of chronic bronchitis among "drooping" cigarette smokers is not due, to any significant extent, to bias in selection or to the other factors considered above.

Presumably, for comparable cigarette consumption, the "drooping" cigarette method of smoking leads to a greater exposure of the bronchi to those substances in tobacco smoke thought likely to be the cause of lung damage seen in chronic bronchitics (Thurlbeck et al., 1963) than does the normal method of smoking. This may not be due solely to the actual volume or concentration of smoke being greater but perhaps because a great proportion of "sidestream" smoke is inhaled. This smoke-that arising from the burning cone and mouthpiece during puff intermissions-may contain significantly more tar than the "mainstream" smoke which emerges from the mouthpiece during puffing (U.S. Department of Health, 1972).

\section{Conclusions}

This investigation has shown that those cigarette smokers who do not usually remove the cigarette from the mouth between puffs have a significantly higher rate of chronic bronchitis than those who smoke in the normal manner. Neither bias in selection nor age, cigarette consumption, type of cigarette smoked, or social class differences are thought to have significantly affected this finding. 
Whatever the reason for this excess of chronic bronchitis among the "droopers"-more prolonged and concentrated tobacco smoke exposure or differing proportions of "sidestream" and "mainstream" smoke-there seems little doubt that it is a dangerous method of smoking cigarettes involving greater risk of developing chronic bronchitis and, on the evidence of Brett and Benjamin (1968), of increased mortality from lung cancer than is the normal method.

I wish to thank Professor M. R. Alderson, formerly Director of the Regional Cancer Registration Bureau, who helped plan the investigation, and the Manchester Regional Hospital Board who allowed the staff of the Mass Radiography Service to obtain the histories and the computer section to process the information. I am particularly grateful for the care and attention to detail given by the staffs of these departments.

\section{References}

Brett, G. Z., and Benjamin, B. (1968). British Medical fournal, 3, 82. College of General Practitioners (1961). British Medical fournal, 2, 273. Doll, W. R., and Hill, A. B. (1950). British Medical fournal, 2, 1271.

General Register Office (1960). Classification of Occupations, 1960. London, H.M.S.O.

Higgins, I. T. T. (1959). British Medical fournal, 1, 325.

Lowe, C. R. (1969). British Medical fournal, 1, 463.

Reid, D. D., Anderson, D. O., Ferris, B. G., and Fletcher, C. M. (1964). British Medical fournal, 2, 1487.

Rimington, J. (1969). British fournal of Disease of the Chest, 63, 193.

Rimington, J. (1972). British Medical fournal, 2, 262.

Thurlbeck, W. M., Angus, G. E., and Pare, J. A. P. (1963). British fournal of Diseases of the Chest, 57, 73.

Todd, G. F. (editor) (1969). Statistics of Smoking in the United Kingdom. Research Paper 1, 5th edn. London, Tobacco Research Council.

U.S. Department of Health, Education and Welfare (1972). Health Consequences of Smoking. Washington, U.S. Government Printing Office.

\title{
Recovery of Adrenal Function after Substitution of Beclomethasone Dipropionate for Oral Corticosteroids
}

\author{
D. J. MABERLY, G. J. GIBSON, A. G. BUTLER
}

British Medical fournal, 1973, 1, 778-782

\section{Summary}

Of 16 steroid-dependent asthmatic patients oral treatment has been discontinued in six and reduced in four after the introduction of beclomethasone dipropionate. Substitution of inhaled beclomethasone for oral steroids was unsuccessful in the remaining six patients. Serial adrenal function studies in the patients whose oral treatment was discontinued showed progressive recovery, and five out of six had a normal response to tetracosactrin stimulation after two months.

\section{Introduction}

Various attempts have been made to treat asthma by inhalation of steroids in order to obviate the suppression of adrenal function caused by systemic therapy. Inhalation of dexamethasone, hitherto the most widely used steroid aerosol, has, however, been shown to cause adrenal suppression (Linder, 1964).

Beclomethasone dipropionate is a synthetic steroid which has been in general use for some years as local treatment for various skin disorders. In contrast to other topical steroids which appear to be absorbed through the skin to an extent sufficient to produce adrenal suppression (Scoggins and Kliman, 1965), Raffle and Frain-Bell (1967) showed that there was no fall in morning levels of plasma cortisol in patients treated with topical beclomethasone dipropionate. This finding prompted studies of the possible benefits of inhaled beclomethasone in asthma, but the experience of different investigators has so far been mixed. Morrow Brown et al. (1972) showed

\footnotetext{
Department of Medicine, Royal Postgraduate Medical School and Hammersmith Hospital, London W12

D. I. MABERLY, M.R.C.P., M.R.A.C.P., Research Fellow

G. J. GIBSON, B.SC., M.R.C.P., Registrar

Allen and Hanbury's Ltd., Ware, Hertfordshire

A. G. BUTLER, B.Sc., Senior Clinical Trials Officer
}

no evidence of adrenal suppression in asthmatic patients after changing treatment from oral steroids to inhaled beclomethasone but no data were presented on adrenal function before the change, nor was there any biochemical evidence of progressive adrenal recovery. Both Clark (1972) and Lal et al. (1972) showed increases in resting morning cortisol concentrations after changing from systemic steroids to beclomethasone, but some of Clark's patients seemed to have had subnormal responses to tetracosactrin at varying intervals after oral steroids were stopped. Most of the steroid-dependent patients in these studies were satisfactorily transferred to maintenance treatment with beclomethasone in a dose between 300 and $600 \mu \mathrm{g}$ a day. Choo-Kang et al. (1972), however, were unable to control their patients' symptoms on 400 $\mu \mathrm{g}$ of beclomethasone daily. Even with $2 \mathrm{mg}$ a day they found that control was still less satisfactory than with oral steroids, and there was also evidence of suppression of adrenal function.

In this paper we report the effects of substituting inhaled beclomethasone dipropionate for oral steroids in 16 steroiddependent asthmatic patients whose adrenal function was assessed at regular intervals.

\section{Methods}

The clinical characteristics of the 16 patients are shown in table I. All had been on continuous steroid therapy for over two years, 15 of them taking a usual daily dose of $10 \mathrm{mg}$ prednisone or more. These patients were chosen because they were well known to us, their asthma was relatively stable, most of them were experiencing troublesome steroid side effects, and several attempts at withdrawal had proved unsuccessful.

Ventilatory function was assessed by twice-daily readings by the patients of their own peak expiratory flow (PEF) and by measurement at each clinic visit of the forced expired volume in one second $\left(\mathrm{FEV}_{1}\right)$ and vital capacity (VC). Data were collected for four weeks before starting beclomethasone.

The beclomethasone was given by metered aerosol delivering $50 \mu \mathrm{g}$ per puff, initially in a dose of $200 \mu \mathrm{g}$ twice daily. This was later changed to $100 \mu \mathrm{g}$ four times a day or $150 \mu \mathrm{g}$ four times a day in some cases. The patients were in- 